\title{
A bibliometric and classification study of Project-based Learning in Engineering Education
}

\author{
Ana Carla Bittencourt Reis ${ }^{\text {a* }}$, Sanderson César Macêdo Barbalho ${ }^{\mathrm{a}}$, Alline Christine Diniz Zanette \\ aniversidade de Brasília, Brasília, DF, Brazil \\ *anacarlabr@unb.br
}

\begin{abstract}
Engineering education has been the subject of studies in search of approaches that provide better results in terms of learning. The Project Based Learning approach (PBL) is the subject of this study from the point of view of its application in Engineering. The objective is to present a classification and bibliometric analysis of PBL in Engineering. Publications on the subject were identified through queries at the journal databases at ISI Web of Science and Scopus SClmago between 2000 and 2016. The results highlight the benefits from the use of the PBL approach to learning in Engineering showing increased absorption of technical content by students and the development of soft and multi-disciplinary skills. The bibliometric analysis revealed the most relevant journals in the subject, authors and the most cited papers and keywords. New horizons to advance the use of PBL in engineering education are discussed.
\end{abstract}

Keywords

Engineering education. Active learning. Project-based learning.

How to cite this article: Reis, A. C. B., Barbalho, S. C. M., \& Zanette, A. C. D. (2017). A bibliometric and classification study of Project-based Learning in Engineering Education. Production, 27(spe), e20162258. http://dx.doi.org/10.1590/01036513.225816

\section{Introduction}

According to the report of the United Nations Educational, Scientific and Cultural Organization (2010), Engineering is the field or discipline that is related to the acquisition and application of scientific methodology and mathematical knowledge for the development, invention, innovation and use of materials, machinery, structures, systems and processes for specific purposes. According to Taajamaa et al. (2013), the development of interdisciplinary skills of cooperation, project management, soft skills in different contexts etc., has been considered essential for engineers.

Traditional engineering education is considered deductive and, according to Prince \& Felder (2006), in the teaching-learning process the teacher introduces the subject to be studied, usually through lectures, illustrates applications, gives the student a homework, and tests his or her knowledge at the end of the process through the application tests. Alternative approaches for teaching, according to the authors, are called inductive methods. These methods have some aspects in common, such as the fact that they are focused on the student, who assumes more responsibility for his or her own learning, and the fact that they are supported by research. Some examples of these methods may be mentioned: inquiry learning, problem/project based learning (PBL), case-based teaching, discovery learning, and just-in-time teaching (Prince \& Felder, 2006).

Problem/Project-based learning (PBL), object of this study, is an instructional learner-centered approach which empowers learners to conduct research, integrating theory and practice to solve a defined problem or to lead to the production of a final product. The problem/project is usually completed with the presentation of a written and/or oral report, summarizing the procedure used to produce the product. PBL has been widely used in order to develop the students' skills (Soares et al., 2013). In this methodology, the student leaves his passive position to receive educational content, and moves onto a more active stance by associating theory 
learned at university with practice, even during the course (Ríos et al., 2010). An indicative that corroborates the importance of PBL in Engineering Education comes from Jesiek et al. (2011). Their research, made from 2005 to 2008, evidenced that the theme was growing prominently, so the PBL approach is gaining momentum and attention among the researchers.

The literature on teaching and learning approaches has shown to be extensive. Many universities around the world are experiencing a transition between the traditional engineering education and the use of new approaches, for example, PBL. A significant amount of work has been published in recent years and some principles to be highlighted on PBL approach may be mentioned (De Graaff \& Kolmos, 2007):

- Learning is organized around problems. This is a central principle for the development of motivation. The learning process is in a specific context and is based on the learner's experience;

- Interdisciplinary learning, which may span across subject-related limits and methods;

- Team-based learning, which is considered a social act where learning presents itself through dialogue and communication. It can be observed that the students learn from themselves and from each other, sharing knowledge and being part of collaborative learning.

De Graaff \& Kolmos (2007) state that PBL is seen as a way of teaching and learning that is used at certain moments in undergraduate courses, but that is not considered a general strategy of education. Authors as Aquere et al. (2012), Crosthwaite et al. (2006), Gomes et al. (2006) and Smith et al. (2005) show experiences in which PBL is used as a central element along the whole engineering degree courses. These views are not concurrent. Moreover it is necessary to know details about the practices related to applications of such approaches, which points to the need for a literature review that can bring out the authors and the main articles and journals around this theme.

Recent articles in Engineering Education started to study bibliographic data to identify publications trends and their main characteristics. Wankat (2004) analyzed the Journal of Engineering Education content from 1993 to 2002, including data of the most cited keywords and the most cited references and authors. After that, Wankat et al. (2014) wrote about Engineering Education Research in the context of the European Journal of Engineering Education and the Journal of Engineering Education. It was performed a study about the number of citations, reference disciplines, the geographical distribution and collaboration of authors, among other topics. From another perspective, Xian \& Madhavan (2014) conducted a bibliometric analysis for papers and conferences from 2000 to 2011. They identified the main characteristics in the considered period, the authors' background, the research areas and collaboration structures.

Given what was aforementioned, this study aims to carry out a bibliometric classification and analysis on the PBL approach and literature classification from the last sixteen years. The objective is to identify the main journals, authors, papers, countries and study tendencies in the context of the PBL approach applied to engineering education. Additionally, it is performed a classification of the main articles in the area, aiming to identify their features, such as methodological approach, engineering area, educational level, motivation for the use of PBL approach, methodologies and associated approaches and other relevant findings. In general, this paper seeks to obtain a more accurate view of the impact and relevance of articles, as well as identifying current and future research directions.

The following section presents the methodological approach used in this study. Next, the results found are presented in detail, and finally, scientific considerations and practical guidelines for implementing PBL initiatives in engineering are discussed.

\section{Methodology}

The methodology used in this study follows protocols for searching, classification and bibliometric analysis. All the analysis is described in the following paragraphs.

\subsection{Search protocol}

Scientific journals have become the main media of the scientific communication. Strengthened by the institutionalization of science and the specialization of knowledge, they acquired vital importance in efficient, economical and transparent flow of scientific information (Weitzel, 2006). This fact indicates the use of scientific journals as a focus for the execution of bibliometric analysis. 
The most relevant journals in the field of education were initially reviewed to understand where engineering education is placed within a general picture of the area. The expectation was to comprehend the representativeness of the publications in engineering education among all the publications about education. The databases considered to gather these data were the SClmago and the Journal Citation Reports (JCR).

It was selected the category Education in SClmago and all relevant categories in the JCR: Education \& Educational Research; Education, Scientific Disciplines; Education Special. In SClmago, 1066 journals were identified relating to this issue, and 309 journals in JCR, both regarding engineering and other subjects. SClmago and JCR data were then extracted the $17^{\text {th }}$ May 2017 for analyzing the significance of the reviews, according to the SCImago Journal Rank Indicator and the impact factor of the Institute for Scientific Information (ISI) of each journal. The SClmago indicator is the average number of weighted citations received in the correspondent year by the documents published in the three previous years. The ISI impact factor is calculated by dividing the number of current year citations by the number of items published in that journal in the previous two years (The Institute for Scientific Information, 1994).

Until 2004, the ISI Web of Science was the only international and multidisciplinary database available to obtain data from a vast number of fields (Vieira \& Gomes, 2009), where one can identify all journals whose impact factor is indexed in JCR. Nevertheless, some authors support the use of other databases when the objective is to perform a systematic review; according to Borrego et al. (2014), searching in a wide variety of databases ensures that the relevant studies are located. Following this approach, the ISI Web of Science, Scopus and Science Direct were used as searching tools, mainly due to the fact that one can relatively easily export and handle the data available through them. The search procedures took place the $19^{\text {th }}$ of January 2017.

In this context, a search using the terms "Engineering Education" and "Project-Based Learning or Problem-Based Learning" was performed for the period that ranges from 2000 to 2016. A refinement was proceeded, taking only articles published in journals. As a result, 624 articles were identified in total, 460 unique records.

\subsection{Bibliometric analysis and protocol}

Bibliometrics regards the aspects of the study to be conducted by incorporating the counting of articles, publications, citations, i.e., statistically significant manifestations of information which was stored irrespective of the area of knowledge (Groos \& Pritchard, 1969). In this work, bibliometrics is used to determine an overview of the major journals, countries, authors and articles in the study area, reported in section 3.2.In this sense, the work is composed by two main parts related to bibliometric analysis, namely: (1) Analysis of journals, authors and articles; (2) Keyword Analysis.

In the analysis of journals, authors and articles, a study was conducted on the importance of engineering education journals as compared to other education journals. After applying the search protocol, quantitative citations and publications on the subject were evaluated, separated by country, journals and studied articles. The citations analysis has been used as a measure to study communication (Zhao \& Logan, 2002), allowing the evaluation of scientific information (Franck, 1999) and enabling the assessment of the type of collected information and guiding the reader to sources of knowledge on the subject. In the last three decades, citation analysis has been increasingly used to quantify the importance of researchers and scientific research and it is the main item considered in the calculation of the impact factor of the JCR (Meho, 2007).

For keyword analysis, a study of identified publications was conducted and the keywords were counted. According to De Bellis (2009), in keyword analysis itis assumed that authors choose scientific terms out of a finite and encoded repertoire, using different terms when they postulate nontrivial relationships between concepts. In this case, the recognition of same relationship between words by different authors reveals something about the cognitive structure of the research area studied. The usefulness of the study of keywords is cited by several authors, both to analyze the content of publications and to investigate trends in the study area (Salton \& McGill, 1983; Elam et al., 1986; Barki et al., 1993). As a result of this phase, the most important research topics are identified in the study area.

\subsection{Classification protocol}

The 460 publications (according to the section 2.1) were ordered, in each database, from the most cited to the less cited in average citations per year. It was found that 50\% of the cumulative average citations per year were related to 68 works in total, considering the three databases (ISI Web of Science, Scopus e Science Direct), corresponding to 49 unique records, after the exclusion of the repeated papers. 
The documents which the authors did not have access were removed from these 49. After this refinement, 45 articles remained, which are explored in detail in the Classification section (3.1). The articles' information is available in the Appendix A.

Firstly all 45 articles were sorted by the three authors. They analyzed some of these articles and found the main topics related to the PBL theory. An initial classification table was constructed and its content was discussed for alignment. In order to achieve more representativeness from the sample, the first sorting was done by publication year. One researcher was responsible for the first years of the timeframe, and the other researchers for the subsequent ones, to know, the intermediate and final years. Thus, each researcher was able to develop a first view of the main topics over a specific period. After a deliberation, the table suffered only a few adjustments.

The table and all articles were available at a common drive in a cloud system, available to the three researchers. As long as the authors were advancing in the articles analysis and in their classification process, some doubts emerged and they were discussed by all the researchers, who accessed the databases to read the text for alignment of the classification. At the end, the classification of the articles was reviewed by the researchers to assure a consistent understanding of the whole sample. When any topic raised a doubt, a discussion was performed to achieve a consensus.

Each article selected was individually registered in filing. The papers were then classified according to the methodological approach (survey research, case study, experience description, literature review, experiment; cohort study and system description); countries originating the work; engineering area (Electrical, Civil, Chemical etc.); educational level (high school, undergraduation, graduation); motivation for the use of PBL approach; tools, methodologies or associated approaches (included other teaching-learning approaches, software, etc.); and relevant findings.

\section{Results}

The results of this study are presented in two sections. Section 3.1 is dedicated to the bibliometric analysis and 3.2 is dedicated to the classification results and qualitative analysis of the articles.

\subsection{Bibliometric analysis}

Bibliometric analysis aims to explore aspects related to publications on the subject and is presented in four sub-items: general sample information; analysis of journals; analysis of authors and articles; and keyword analysis.

\subsubsection{General information}

The importance of the topic PBL in Engineering was analyzed. Figure 1 shows the evolution of publications in the period 2000-2016.

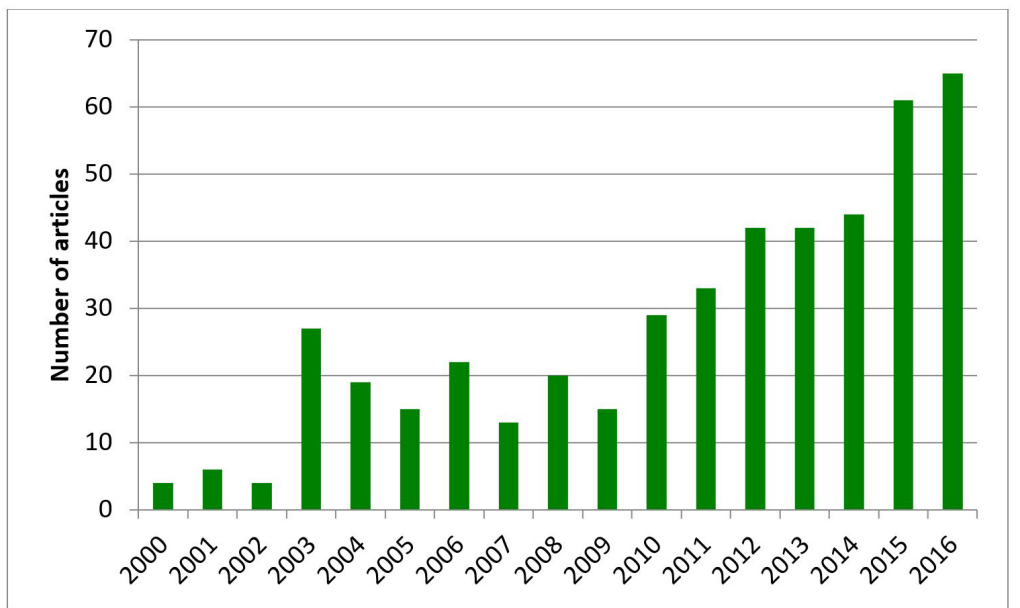

Figure 1. Quantity of 2000-2016 publications. 
Figure 1 shows the amount of publications resulting from the search in the three databases considered (ISI Web of Science, Scopus and Science Direct). It can be noticed a variation of the number of produced papers in the period, with an increasing tendency, up to 65 articles in 2016. In Figures 2 and 3, it is illustrated the number of citations per year registered in the ISI Web of Science and in Scopus, respectively.

It is possible to notice that researchers are taking more interest in the subject over time, due to the significant increase in the quantity of citations received over the years. Similar data to those depicted in the Figure 2 and 3 are not available in the Science Direct database.

Figure 4, which considered data available in ISI Web of Science, Scopus and Science Direct, shows the 14 countries, out of 60 , that have contributed with at least 10 out of 460 publications on the analyzed subject. Most of the works come from the US, accounting for 22.4\%, followed by Spain and Australia. Brazilian researchers produced 10 articles. Although some papers in the literature have identified Brazilian experiences, there are still many opportunities for publishing in engineering education in Brazil, which can be exploited by PBL approach. On the other hand, a hypothesis can be suggested ratifying such a situation, considering that the countries that lead the statistics may have consolidated a more integrated research network when considering this type of methodological experience, which makes for their experiences being featured among the main international references.

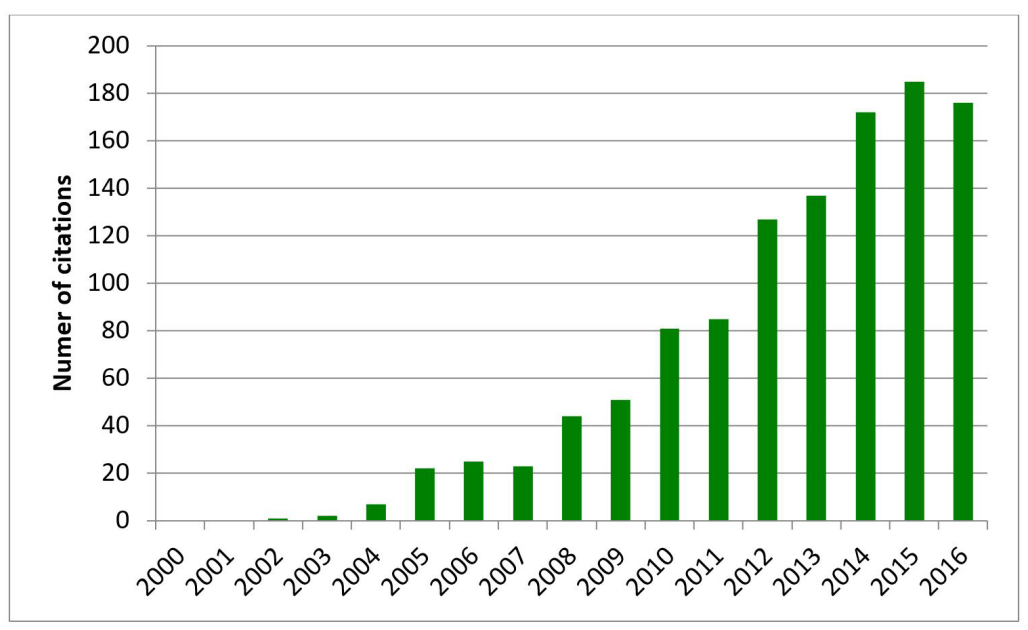

Figure 2. Quantity of 2000-2016 citations registered in the ISI Web of Science.

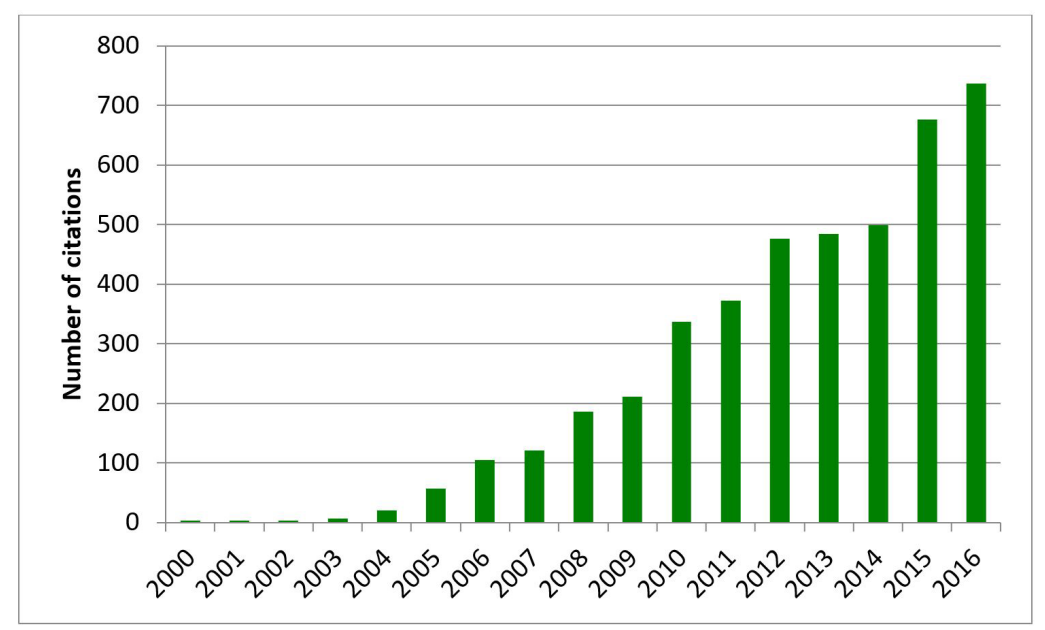

Figure 3. Quantity of 2000-2016 citations registered in Scopus. 


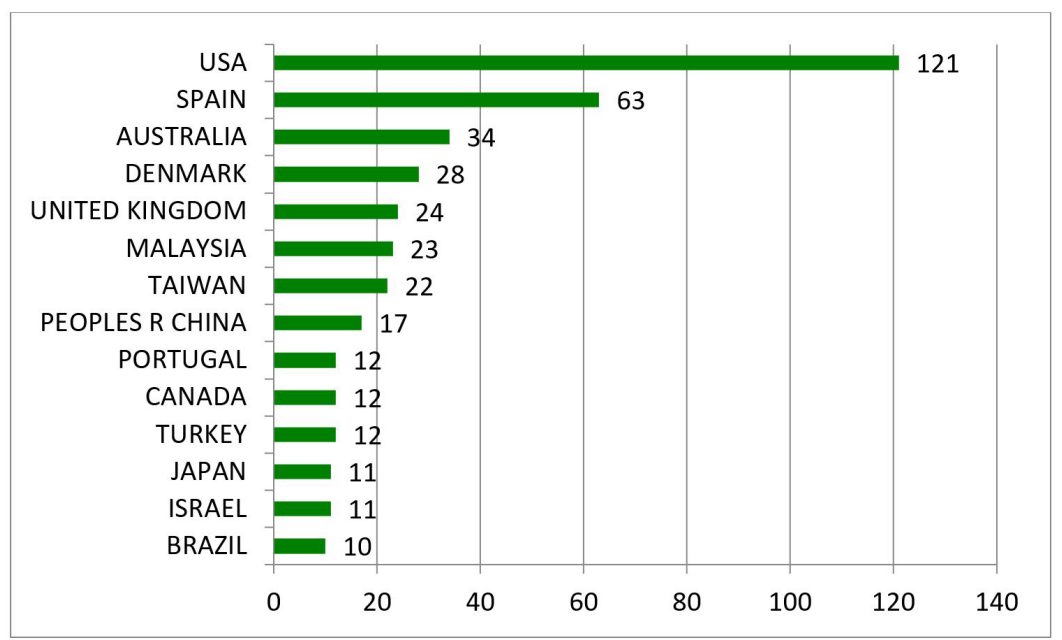

Figure 4. Distribution of articles by country.

\subsubsection{Analysis of journals}

A selection was made of the most relevant journals in the field of education, for understanding where engineering education is placed in such a broad scenario. Initially, according to the Search Protocol in section 2.1, 309 journals were found in the JCR database and 1066 in SClmago.

In the JCR database, the journal with the highest impact factor in Education with a focus on engineering was the Journal of Engineering Education, corresponding to 1.739. It is important to notice that this journal was only the $48^{\text {th }}$ place in the classification given by the database. When it is considered the SClmago database, the Journal of Engineering Education presents the highest SCImago Journal Ranking Indicator, 6.176, considering all the subjects in the Education field, such as it was considered in the JCR search. This difference might be related to the databases' indicators, which are different, and to the journals in the databases, which are not completely overlapped. Nevertheless, a deeper analysis should be performed to draw consistent conclusions about the divergences.

The 460 selected articles are distributed among 160 journals. The journals with the majority of the records, up to the journal with the highest average cites (Journal of Engineering Education) are presented in Table 1. In this table, in addition to the journals identification, is its quantity of publications, the percentage as compared to total publications and the respective citations information. Thus, International Journal of Engineering Education (IJEE), for example, concentrates 107 of the 460 selected articles, $23.2 \%$ of the total. Besides this can be highly influenced by the number of issues per year and articles per issue, or even by a special issue, data demonstrate this journal have more frequently addressed PBL methods in engineering.

Table 1. Journals with most publications relating to the 460 articles.

\begin{tabular}{lcccrr}
\hline \multicolumn{1}{c}{ Journal Title } & $\begin{array}{c}\text { Number of } \\
\text { papers }\end{array}$ & Percentage & $\begin{array}{c}\text { Journal } \\
\text { lmpact Factor } \\
\text { (JCR Index) }\end{array}$ & Cites & Average cites \\
\hline International Journal of Engineering Education & 107 & $23.2 \%$ & 0.559 & 797 & 7.45 \\
IEEE Transactions on Education & 45 & $98 \%$ & 1.330 & 808 & 17.96 \\
European Journal of engineering education & 31 & $6.7 \%$ & $*$ & 278 & 8.97 \\
Journal of Professional lssues in Engineering Education & 20 & $4.3 \%$ & 0.538 & 210 & 10.50 \\
and Practice & 16 & $3.5 \%$ & 0.302 & 104 & 6.50 \\
International Journal of Electrical Engineering Education & 11 & $2.4 \%$ & 0.935 & 50 & 4.55 \\
Computer Applications in Engineering Education & 10 & $2.2 \%$ & $*$ & 0 & 0.00 \\
Procedia - Social and Behavioral Sciences & 9 & $2.0 \%$ & 0.355 & 113 & 12.56 \\
International Journal of Technology and Design Education & 8 & $1.7 \%$ & 1.739 & 982 & 122.75 \\
Journal of Engineering Education & & & & &
\end{tabular}

*Not available in JCR. 
The first journal of engineering education, Journal of Engineering Education, appears with an impact factor of 1.739 and is responsible for the publication of $1.7 \%$ of articles identified, a total of only 8 articles, but presents the major number of cites, 982, and its citation average is discontinuous from the others.

The total number of citations received by the 460 articles is 5,493 and the most cited journal (Journal of Engineering Education) accounts for almost 18\% of total citations. These results are in accordance with the search performed in the section 2.1, considering the terms "Engineering Education" and "Project-Based Learning or Problem-Based Learning" between 2000 and 2016. It is noticed that some journals with fewer publications on engineering education show, in the analyzed articles, a higher average of citations than that among the most cited. For example, the European Journal of Engineering Education presents fewer citations than the IJEE, but a higher average in citations per article. So, it can be inferred that the number of articles published in a journal in Engineering Education area is not a determinant of the importance of that periodic. The number of citations per paper, the year of publication of these articles, as well as the journals' weight to scientific audience should be observed, in order to understand their representation. One can also assume that the JCR index reinforces the research made by the scientific public for the articles in the journals with higher lmpact Factor, demonstrating a virtuous circle: the higher the JCR, the higher the search for articles in those journals, resulting in higher number of citations and consequent increase of their JCR.

\subsubsection{Analysis of authors and articles}

The authors with the largest number of articles published in the field were also analyzed. Table 2 shows the authors with at least four articles.

Table 2. Authors with greater quantity of publications in the period of 2000-2016.

\begin{tabular}{cc}
\hline Authors & Number of Papers \\
\hline KOLMOS A & 9 \\
LIMA RM & 5 \\
ZHOU CF & 5 \\
BARRY DM & 4 \\
KANEMATSU H & 4 \\
FERNANDES S & 4 \\
MESQUITA D & 4 \\
TSENG KH & 4 \\
LOU SJ & 4 \\
\hline
\end{tabular}

Subsequently, the authors of the articles with highest average citations per year were identified in each database, being presented in Table 3 the articles with cites average per year higher than 4 . To select these papers, it was calculated a mean of the "Cites average per year" (equals 1.1) and calculated the standard deviation of all the 460 documents (equals 2.9). Thus, it were considered the articles with cites average per year above the mean plus a standard deviation. Together, these articles have an average of 8.7 citations per year, which is much higher than the overall average (1.12). It can be considered therefore that these articles have a high impact factor regarding the topic PBL in Engineering Education. Thus, in a review of literature, the exclusion of these articles from the references would be an important lapse, because they form the basis of scientific research on the subject, in the period 2000-2016. The database Science Direct did not present any article with cites average per year higher than the established limit.

It is observed that the majority of citations in the discipline of PBL in Engineering Education is concentrated in the Scopus database, followed by ISI Web. It can be verified in the Table 3 that the articles "Characteristics of problem-based learning" and "Using LEGO NXT mobile robots with LabVIEW for Undergraduate Courses on Mechatronics" are among the most relevant in both $\mathrm{SSI}$ Web and Scopus.

\subsubsection{Keyword analysis}

To identify paths for further research, a quantitative criteria was applied for keywords analysis. Considering the keywords counting in all the 460 articles considered in this study, it is possible to identify the most relevant themes in the area. 
Table 3. Most cited articles and their respective authors per database.

\begin{tabular}{|c|c|c|c|c|}
\hline \multirow{2}{*}{ Title } & \multicolumn{2}{|c|}{ Cites } & \multicolumn{2}{|c|}{$\begin{array}{l}\text { Average } \\
\text { citations / year }\end{array}$} \\
\hline & Scopus & ISI & Scopus & ISI \\
\hline $\begin{array}{l}\text { Prince \& Felder (2006). Inductive teaching and learning methods: Definitions, comparisons, and } \\
\text { research bases }\end{array}$ & 671 & & 61.0 & \\
\hline $\begin{array}{l}\text { Yadav et al. (2011). Problem-based learning: Influence on students' learning in an electrical } \\
\text { engineering course }\end{array}$ & 107 & & 17.8 & \\
\hline De Graaff \& Kolmos (2003). Characteristics of problem-based learning & 230 & 99 & 16.4 & 6.7 \\
\hline $\begin{array}{l}\text { Gomez-de-Gabriel et al. (2011). Using LEGO NXT mobile robots with LabVIEW for undergraduate } \\
\text { courses on mechatronics }\end{array}$ & 63 & 30 & 10.5 & 4.3 \\
\hline $\begin{array}{l}\text { Behrens et al. (2010). MATLAB meets LEGO Mindstorms: a freshman introduction course into } \\
\text { practical engineering }\end{array}$ & 68 & & 9.7 & \\
\hline $\begin{array}{l}\text { Lehmann et al. (2008). Problem-oriented and project-based learning (POPBL) as an innovative } \\
\text { learning strategy for sustainable development in engineering education }\end{array}$ & 86 & & 9.6 & \\
\hline $\begin{array}{l}\text { Costa et al. (2007). Applying the problem-based learning approach to teach elementary circuit } \\
\text { analysis }\end{array}$ & 64 & & 9.1 & \\
\hline $\begin{array}{l}\text { Macías-Guarasa et al. (2006). A project-based learning approach to design Electronic Systems } \\
\text { Curricula }\end{array}$ & 93 & & 8.5 & \\
\hline $\begin{array}{l}\text { Frank et al. (2003). Implementing the project-based learning approach in an academic engineering } \\
\text { course }\end{array}$ & 107 & & 7.6 & \\
\hline $\begin{array}{l}\text { Montero \& González (2009). Student engagement in a structured problem-based approach to } \\
\text { learning: A first-year electronic engineering study module on heat transfer }\end{array}$ & 51 & & 6.4 & \\
\hline $\begin{array}{l}\text { McLurkin et al. (2013). Using multi-robot systems for engineering education: Teaching and } \\
\text { outreach with large numbers of an advanced, low-cost robot }\end{array}$ & 24 & & 6.0 & \\
\hline Chau (2007). Incorporation of sustainability concepts into a civil engineering curriculum & 59 & & 5.9 & \\
\hline $\begin{array}{l}\text { Bellmunt et al. (2006). A distance PLC programming course employing a remote laboratory based } \\
\text { on a flexible manufacturing cell }\end{array}$ & 62 & & 5.6 & \\
\hline Huntzinger et al. (2007). Enabling sustainable thinking in undergraduate engineering education & 55 & & 5.5 & \\
\hline $\begin{array}{l}\text { Zou et al. (2012). A problem and Project-Based learning (PBL) approach to motivate group } \\
\text { creativity in engineering education }\end{array}$ & 27 & & 5.4 & \\
\hline $\begin{array}{l}\text { Kumar \& Hsiao (2007). Engineers learn "soft skills the hard way": planting a seed of leadership in } \\
\text { engineering classes }\end{array}$ & 50 & & 5.0 & \\
\hline Santos-Martin et al. (2012). Problem-based learning in wind energy using virtual and real setups & 25 & & 5.0 & \\
\hline $\begin{array}{l}\text { De los Ríos-Carmenado et al. (2015). Promoting professional project management skills in } \\
\text { engineering higher education: project-based learning (PBL) strategy }\end{array}$ & 9 & & 4.5 & \\
\hline $\begin{array}{l}\text { Edström \& Kolmos (2014). PBL and CDIO: complementary models for engineering education } \\
\text { development }\end{array}$ & 13 & & 4.3 & \\
\hline $\begin{array}{l}\text { Fernandes et al. (2014). Engaging students in learning: findings from a study of project-led } \\
\text { education }\end{array}$ & 13 & & 4.3 & \\
\hline $\begin{array}{l}\text { Bielefeldt et al. (2010). Measuring the value added from service learning in project-based } \\
\text { engineering education }\end{array}$ & 30 & & 4.3 & \\
\hline $\begin{array}{l}\text { Steinemann (2003). Implementing sustainable development through problem-based learning: } \\
\text { Pedagogy and practice }\end{array}$ & 57 & & 4.1 & \\
\hline Pandy et al. (2004). Assessing adaptive expertise in undergraduate biomechanics & 52 & & 4.0 & \\
\hline $\begin{array}{l}\text { Martinez-Mones et al. (2005). Multiple case studies to enhance project-based learning in a } \\
\text { computer architecture course }\end{array}$ & 48 & & 4.0 & \\
\hline Vallim et al. (2006). Practicing engineering in a freshman introductory course & 44 & & 4.0 & \\
\hline Palmer \& Hall (2011). An evaluation of a project-based learning initiative in engineering education & 24 & & 4.0 & \\
\hline
\end{tabular}

The keywords more frequently found within the papers resulting from the search conducted in the three databases can be seen in the Table 4 . The keywords showed present 12 or more occurrences in the analyzed articles. It can be inferred that trends for future research might be identified in these keywords.

In spite of the fact that some relations are trivial, for example between "Project based learning" and "Collaborative learning" or "Students", it can be assumed that authors chose the terms in Table 4 to postulate nontrivial relationships between concepts. In this case, the recognition of same relationship between words by different authors reveals something about the cognitive structure of the research area studied.

Comments can be addressed on the relationship between the research areas represented by the keywords that do not relate directly to the search conducted in the databases ("Engineering Education AND (Project Based Learning OR Problem Based Learning”)) in the Table 4. First, the term "Active learning" refers directly to the PBL method, in which the students are responsible for their own learning, leading to improved motivation 
Table 4. Most cited keywords and respective counting.

\begin{tabular}{lc}
\hline \multicolumn{1}{c}{ Keywords } & Counting \\
\hline Project Based Learning & 234 \\
Engineering education & 233 \\
Problem Based Learning & 189 \\
Education & 38 \\
Active learning & 30 \\
Design & 27 \\
PBL & 24 \\
Assessment & 16 \\
Higher Education & 16 \\
Students & 16 \\
Collaborative learning & 15 \\
Mechatronics & 15 \\
Teamwork & 15 \\
Curricula & 14 \\
Innovation & 14 \\
Software Engineering Education & 14 \\
Sustainability & 14 \\
Learning & 13 \\
Curriculum Development & 12 \\
\hline
\end{tabular}

levels. The term "Design" reflects the need to use PBL for effective teaching of engineering design itself. Next, it is noted the concept of mechatronics, which is an inherently multidisciplinary field, in which the learning requires a strong interaction between knowledge of various engineering areas and whose project activities involve integration challenges that can hardly be taught without an eminently practical approach. The multidisciplinary demand can explain the keyword sustainability as well.

An interesting analysis can be abstracted from the fact that the keywords "Innovation" is strongly associated to PBL. In fact, the PBL approach is still considered an innovation in the Engineering Education, mainly if it is made a comparison with the medicine field. The term "Innovation" also can suggest the use of PBL as a methodology for teaching in situations where professors want more innovative results from students. The PBL allows the student to develop his technical and soft skills, such as teamwork, and one of its main goals is to augment the student motivation. The term "Software engineering education" has relation to the main concern of PBL approach in a sense of teaching engineering knowledge in an innovative and more motivated way, due to the skills needed for software professionals nowadays.

\subsection{Classification}

As mentioned in the Classification Protocol section, the 460 publications were ordered, in each database, from the most cited to the less cited in average citations per year. It was calculated the top 50\% of the cumulative average citations per year in each of them. This amount corresponds to 68 works in total, 49 unique records. From these 49, 4 articles were suppressed because they were not open source and could not be found using other techniques. Thus 45 articles were considered for further classification analysis in all the topics.

Under the classification analysis some qualitative data were gathered by means of literature review and discussion by the research team. A datasheet was built summarizing each classification in order to plot graphs and tables for data understanding. The first analysis aimed to sort the works by type of methodology used. In the analysis of the methodological approach, the work was classified as survey research, case study, experience description, literature review, experiment, system description and cohort study.

Survey Research is used to quantitatively describe specific aspects of a given population, students or teachers in PBL experiences. The case study is an intensive study of a single unit in order to assist the understanding of a larger class of similar units (Gerring, 2004). The literature review consists of evaluative studies of PBL area, which should report and describe the existing claims in the literature and critically examine research methods to assess whether statements are correct and clarify them (Boote \& Beile, 2005). As per experiment, the experiences were classified as they were carried out where a group of students underwent active methodology based on projects, and a control group underwent a conventional methodology on the same theme, and both groups 
were evaluated based on similar final examinations. Even though the experiment is most frequently used in the medical and exact sciences, it is used in social research when using a control group to verify the impact of any approach or improvement applied to a given system (Dane, 1990).

System description is the classification used to refer to work on a given software used to implement a PBL experience. Anyway, the named descriptive of the experience are papers describing an application of PBL approach in a given context. It differs from the case study because it is not an analysis of a foreign researcher on a given situation, but in fact a description of how the PBL methodology is used in a particular university. Did not qualify this type of study as action research (Dane, 1990) because it was not used a research protocol to perform the application of PBL practices.

In a cohort study, an outcome study population is first identified by its exposure to the PBL approach. The same group is followed in time and analyzed prospectively, allowing the assessment of possible causalities due to the temporal framework (Song \& Chung, 2010). Figure 5 shows the results of this classification.

The case studies prevailed in the articles analyzed, followed by the description of experience. The literature reviews were limited to the beginning of the period and not featured in more current publications, which can denote a higher maturity, from the point of view of the application of the concepts of PBL. The surveys, for example, are characteristic of research topics that are more consolidated, in which you can create a standard framework in the form of a questionnaire that will be understood by different audiences depending on the massification of the concepts involved.

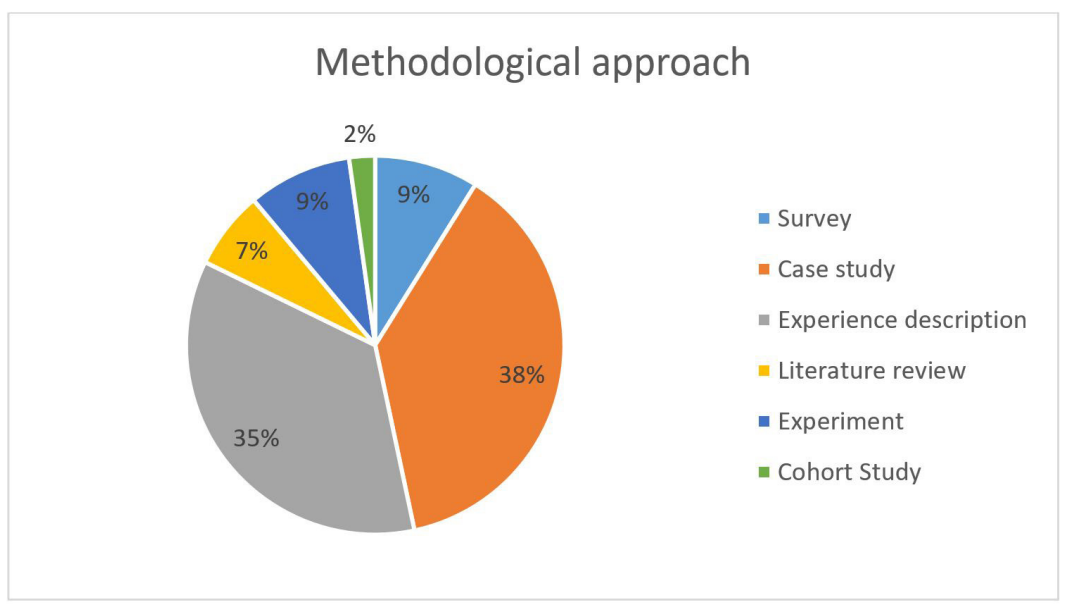

Figure 5. Stratification of the work in accordance with the methodological approach used.

This work investigates the PBL approach in engineering and among the areas of engineering, in order to know if some specific field is more interested on active learning methods than others (Figure 6). In the identified articles there is an emphasis on electrical engineering and engineering in general, which infers that most of the work indicates the possibility of using PBL in any area of engineering.

Regarding the level of education (high school, undergraduation and graduation), most studies are focused on undergraduation, which corresponds to $77 \%$ of the papers reviewed. Some of these studies have reported on the use of the PBL approach and the gains by its use in comparison to the traditional approach.

In a qualitative analysis of the articles considered here, PBL practices were applied to students in more advanced stages of their undergraduate courses than the freshmen. In addition, data gathered from the analysis allows to reveal the limited use of active methodology in graduate, which, on one hand can reflect the fact that at this stage of career development, there is a more likely choice for a scientific training, and on the other hand for the use of a more formal approach.

Besides the classification, an article report was carried out for each article, in order to further analyze each one, qualitatively. One of the elements analyzed in the reports was the motivation for the use of the PBL approach, because motivation exposes the reasons that led the authors to research the subject or use it in their academic activities. Basically, the intention was to identify in this work the justification presented by the authors to study and use PBL. The following identified reasons can be mentioned: 


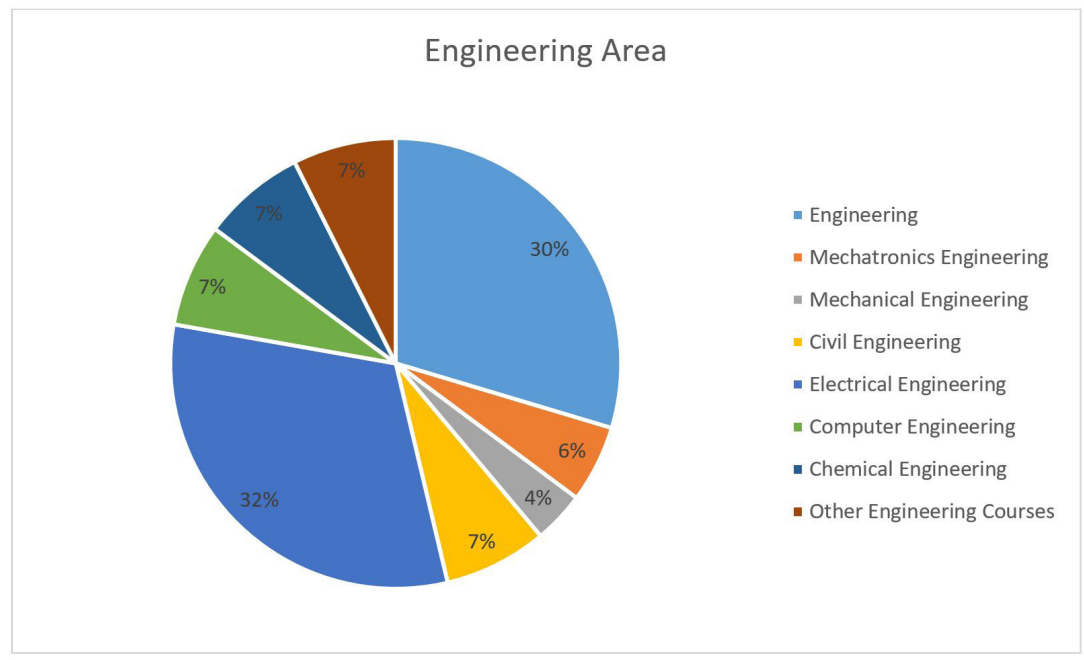

Figure 6. Stratification of the works according to engineering area.

- BL is the most suitable pedagogical model for teaching projects;

- Adaptation to the new demands of employers and industries;

- Preference for inductive methods;

- Increasing the involvement of students;

- Emphasis in practical aspects and problems;

- Stimulation of students interest in the courses and prevention of motivation drops;

- The maximization of learning outcomes and promotion of the acceleration of the learning curve;

- Development of soft and technical skills.

In the selected articles, among the highlighted skills developed by the students, it is possible to point out pro-activity, teamwork, autonomy, communication, commitment; increase the depth and breadth of knowledge, professionalism, sense of community, problem-solving skills, innovative thinking, critical thinking, creativity, design capacity; in addition to the development of traditional technical skills in engineering.

One can also mention the fact that the interaction of academia with industry and society provided by PBL practices, have a social impact by promoting issues of improvement involving the community, which provides the student with a broader perspective of the issues they relate to their profession, such as social, environmental, economic and cultural.

Other approaches have been used in combination with PBL such as cross disciplinary team learning, experiential learning, virtual laboratories, knowledge landscape approach, and behavioral theories (Gomez-de-Gabriel et al., 2011; Chinowsky et al., 2006). In addition to the mentioned approaches, some techniques have been applied in the progress of projects, such as virtual meetings, e-learning, skill sections, game elements, Matlab, robots and communities of practice, among others (Prince \& Felder, 2006; Bellmunt et al., 2006; Behrens et al., 2010; McLurkin et al., 2013; Santos-Martin et al., 2012; Soares et al., 2014; Hosseinzadeh \& Hesamzadeh, 2012; Warren et al., 2012). Finally, as a tool for evaluation, peer evaluation was used in the composition of students' grades (De los Ríos-Carmenado et al., 2015; Chau, 2007; Palmer \& Hall, 2011; Hosseinzadeh \& Hesamzadeh, 2012; Mantri et al., 2008; Hersam et al., 2004; Rodríguez et al., 2015; Kumar \& Hsiao, 2007).

In some studies, it was demonstrated that applying the PBL approach the students were more motivated, were able to develop soft skills, and had better academic results, (Prince \& Felder, 2006; Costa et al., 2007; Behrens et al., 2010; Martinez-Mones et al., 2005; Frank et al., 2003; Macías-Guarasa et al., 2006; Gomez-deGabriel et al., 2011; Montero \& González, 2009; Vallim et al., 2006; Mantri et al., 2008; Hersam et al., 2004; Rodríguez et al., 2015; Doppelt, 2009; Garcia \& Pacheco, 2014; Ragusa \& Lee, 2012; Gomes et al., 2006). In addition, some authors proposed competitions to stimulate the students' motivation (Gomez-de-Gabriel et al., 2011; Wang et al., 2012; Frank et al., 2003; Tseng et al., 2013). 
Nevertheless, some negative aspects were identified, for instance the high time demands for project work (Palmer \& Hall, 2011; Santos-Martin et al., 2012); the students consider that they get lower returns in terms of grades, when compared to the traditional courses (Fernandes et al., 2012; Warren et al., 2012); some lecturers seen PBL programs as more time consuming (Rodriguez et al., 2015); students report weakness on programs on support conflict resolution and team building (Soares et al., 2013).

\section{Conclusions}

The classification and bibliometric study provided some insights on recent publications involving PBL approach. Through the classification study, it was possible to observe aspects such as the methodological approach, engineering area, level of education, motivation for use of PBL approach, tools, methodologies or approaches associated and relevant findings.

The classification study allowed to identify operational details of the experiments and research described in the literature, as well as the motivation to use PBL approach for studies. Many aspects have been identified and there is a focus on improving the pedagogical model used in several universities with a view to seeking to maximize learning outcomes. It is believed that the development of skills of engineering students through practical projects involving real-world situations increases their learning and provides better preparation for professional practice. Another relevant question found refers to the skills developed by the students in achieving the projects, as pro-activity, teamwork, autonomy, communication, commitment, problem-solving skills, innovative thinking, critical thinking, creativity and design capability. Additionally, other methodologies were used in combination with PBL, as well as software and techniques for conducting projects.

The results presented by the authors point out many positive aspects for teaching and learning, for example, more motivated students, improvement of skills in finding practical solutions, improved academic performance and improved marketing.

The bibliometric analysis explored aspects related to the analysis of journals, authors, articles, citations and keywords. In the analysis of journals, it was possible to identify that the education journal focusing on engineering (Journal of Engineering Education) with the highest impact factor (1.739) occupies the 48th rank in the ranking of education area revision by the JCR. When it is considered the SClmago database, the same journal is in the first place in the SClmago Journal Ranking Indicator, 6.176, considering all the subjects in the Education field. This difference might be related to the databases' different indicators and journals.

The number of publications in the area is not regular, despite the fact that is has a significant quantity. However, citation analysis shows an increasing interest in the subject, particularly the Journal of Engineering Education that focuses most of citations between 2000 and 2016. The authors who account for the majority of publications are Kolmos, Lima and Zhou, respectively. The countries with most of the publications are the United States and Spain.

From the citation analysis, it was possible to identify the most relevant publications about PBL in engineering and the amount of articles studied was considered representative. The articles "Characteristics of problem-based learning" and "Using LEGO NXT Mobile Robots with LabVIEW for Undergraduate Courses on Mechatronics" are among the most relevant in both ISI Web and Scopus.

In keyword analysis an objective criteria to infer the direction of new research on PBL engineering were used. In addition to Project/Problem Based Learning and Engineering Education, the following keywords may be highlighted: Active learning, Design, Higher education, Mechatronics, Assessment, Innovation, Software engineering education, Sustainability among others.

The analysis of the keywords not directly involved in engineering education identified convergences and directions for future research. It includes the aspect of the multidisciplinary feature of mechatronics and sustainability, and its impact on the approach used for teaching; and aspects related to project planning and possible impact that the PBL initiatives would have on professionals in the area of projects, especially training them for planning on their future tasks in interdisciplinary endeavors.

As work limitations one can consider that the search protocol itself implied in more generic work on teaching experiences with PBL engineering. More studies related to specific areas of engineering, for example, project management or engineering design, could result in another set of publications. Some traditional areas of human and social sciences, such as economics, psychology and management, could be incorporated in the research universe, because especially in industrial engineering there is a great interface with such areas, which was not captured in the studied sample. 


\section{References}

Aquere, A. L., Mesquita, D., Lima, R. M., Monteiro, S. B. S., \& Zindel, M. (2012). Coordination of student teams focused on project. International Journal of Engineering Education, 28, 859. Retrieved in 24 August 2016, from http://hdl.handle.net/1822/18818

Barki, H., Rivardi, S., \& Talbot, J. (1993). A keyword classification scheme for IS research literature: an update. Management Information Systems Quarterly, 17(2), 209-226. http://dx.doi.org/10.2307/249802.

Behrens, A., Atorf, L., Schwann, R., Neumann, B., Schnitzler, R., Balle, J., Herold, T., Telle, A., Noll, T. G., Hameyer, K., \& Aach, T. (2010). MATLAB meets LEGO Mindstorms: a freshman introduction course into practical engineering. IEEE Transactions on Education, 53(2), 306-317. http://dx.doi.org/10.1109/TE.2009.2017272.

Bellmunt, 0. G., Miracle, D. M., Arellano, S. G., Sumper, A., \& Andreu, A. S. (2006). A distance PLC programming course employing a remote laboratory based on a flexible manufacturing cell. IEEE Transactions on Education, 49(2), 278-284. http://dx.doi.org/10.1109/ TE.2006.873982.

Bielefeldt, A. R., Paterson, K. G., \& Swan, C. W. (2010). Measuring the value added from service learning in project-based engineering education. International Journal of Engineering Education, 26(3), 535-546. Retrieved in 24 August 2016, from http://www.ijee.ie/ contents/c260310.html

Boote, D. N., \& Beile, P. (2005). Scholars before researchers: on the centrality of the dissertation literature review in research preparation. Educational Researcher, 34(6), 3-15. http://dx.doi.org/10.3102/0013189X034006003.

Borrego, M., Foster, M. J., \& Froyd, J. E. (2014). Systematic literature reviews in engineering education and others developing interdisciplinary fields. Journal of Engineering Education, 103(1), 45-76. http://dx.doi.org/10.1002/jee.20038.

Chandrasekaran, S., Stojcevski, A., Littlefair, G., \& Joordens, M. (2013). Project-oriented design-based learning: aligning students' views with industry needs. International Journal of Engineering Education, 29(5), 1109-1118. Retrieved in 2 March 2017, from http:// www.ijee.ie/contents/c290513.html

Chau, K. W. (2007). Incorporation of sustainability concepts into a civil engineering curriculum. Journal of Professional Issues in Engineering Education and Practice, 133(3), 188-191. http://dx.doi.org/10.1061/(ASCE)1052-3928(2007)133:3(188).

Chinowsky, P. S., Brown, H., Szajnman, A., \& Realph, A. (2006). Developing knowledge landscapes through project-based learning. Journal of Professional Issues in Engineering Education and Practice, 132(2), 118-124. http://dx.doi.org/10.1061/(ASCE) 10523928(2006)132:2(118).

Costa, L. R. J., Honkala, M., \& Lehtovuori, A. (2007). Applying the problem-based learning approach to teach elementary circuit analysis. IEEE Transactions on Education, 50(1), 41-48. http://dx.doi.org/10.1109/TE.2006.886455.

Crosthwaite, C., Cameron, 1., Lant, P., \& Litster, J. (2006). Balancing curriculum processes and content in a project centred curriculum: in pursuit of graduate attributes. Education for Chemical Engineers, 1(1), 39-48. http://dx.doi.org/10.1205/ece.05002.

Dane, F. C. (1990). Research methods. Pacific Grove: Brooks/Cole Publishing Company.

De Bellis, N. (2009). Bibliometrics and citation analysis: from the science citation index to cybermetrics. Lanham: The Scarecrow Press.

De Graaff, E., \& Kolmos, A. (2003). Characteristics of problem-based learning. International Journal of Engineering Education, 19(5), 657-662. Retrieved in 2 March 2017, from http://www.ijee.ie/contents/c190503.html

De Graaff, E., \& Kolmos, A. (2007). Management of change: implementation of problem-based and project-based learning in engineering. Rotterdam: Sense Publishers.

De los Ríos-Carmenado, l., López, F. R., \& García, C. P. (2015). Promoting professional project management skills in engineering higher education: project-based learning (PBL) strategy. International Journal of Engineering Education, 31(1), 184-198. Retrieved in 24 August 2016, from http://www.jjee.ie/contents/c310115B.html

Ditcher, A. K. (2001). Effective teaching and learning in higher education, with particular reference to the undergraduate education of professional engineers. International Journal of Engineering Education, 17(1), 24-29. Retrieved in 2 March 2017, from http:// www.ijee.ie/contents/c170101.html

Doppelt, Y. (2009). Assessing creative thinking in design-based learning. International Journal of Technology and Design Education 19(1), 55-65. http://dx.doi.org/10.1007/s10798-006-9008-y.

Edström, K., \& Kolmos, A. (2014). PBL and CD10: complementary models for engineering education development. European Journal of Engineering Education, 39(5), 539-555. http://dx.doi.org/10.1080/03043797.2014.895703.

Elam, J., Huber, G., \& Hurt, M. (1986). An examination of the DDS Literature (1975-1985). In E. R. McLean \& H. Sol (Eds.), Decision support systems: a decade in perspective. Amsterdam: Elsevier Science.

Fernandes, S., Flores, M. A., \& Lima, R. M. (2012). Students' views of assessment in project-led engineering education: findings from a case study in Portugal. Assessment \& Evaluation in Higher Education, 372), 163-178. http://dx.doi.org/10.1080/02602938.2010.515015.

Fernandes, S., Mesquita, D., Flores, M. A., \& Lima, R. M. (2014). Engaging students in learning: findings from a study of project-led education. European Journal of Engineering Education, 39(1), 55-67. http://dx.doi.org/10.1080/03043797.2013.833170.

Franck, G. (1999). Scientific communication: a vanity fair? Science, 286(5437), 53-55. http://dx.doi.org/10.1126/science.286.5437.53.

Frank, M., Lavy, 1., \& Elata, D. (2003). Implementing the project-based learning approach in an academic engineering course. International Journal of Technology and Design Education, 13(3), 273-288. http://dx.doi.org/10.1023/A:1026192113732.

Garcia, 1. A., \& Pacheco, C. L. (2014). Using TSPi and PBL to support software engineering education in an upper-level undergraduate course. Computer Applications in Engineering Education, 22(4), 736-749. http://dx.doi.org/10.1002/cae.21566.

Gerring, J. (2004). What is a case study and what is it good for? The American Political Science Review, 98(2), 341-354. http://dx.doi. org/10.1017/S0003055404001182.

Gomes, V. G., Barton, G. W., Petrie, J. G., Romagnoli, J., Holt, P., Abbas, A., Cohen, B., Harris, A. T., Haynes, B. S., Langrish, T. A. G., Orellana, J., See, H. T., Valix, M., \& White, D. (2006). Chemical engineering curriculum renewal. Education for Chemical Engineers, 1(1), 116-125. http://dx.doi.org/10.1205/ece.06020. 
Gomez-de-Gabriel, J. M., Mandow, A., Fernandez-Lozano, J., \& Garcia-Cerezo, A. J. (2011). Using LEGO NXT mobile robots with LabVIEW for undergraduate courses on mechatronics. IEEE Transactions on Education, 54(1), 41-47. http://dx.doi.org/10.1109/ TE.2010.2043359.

Groos, O. V., \& Pritchard, A. (1969). Documentation notes. The Journal of Documentation, 25(4), 344-349. http://dx.doi.org/10.1108/ eb026482.

Hersam, M. C., Luna, M., \& Light, G. (2004). Implementation of interdisciplinary group learning and peer assessment in a nanotechnology engineering course. Journal of Engineering Education, 93(1), 49-57. http://dx.doi.org/10.1002/j.2168-9830.2004.tb00787.x.

Hosseinzadeh, N., \& Hesamzadeh, M. R. (2012). Application of project-based learning (PBL) to the teaching of electrical power systems engineering. IEEE Transactions on Education, 55(4), 495-501. http://dx.doi.org/10.1109/TE.2012.2191588.

Huntzinger, D. N., Hutchins, M. J., Gierke, J. S., \& Sutherland, J. W. (2007). Enabling sustainable thinking in undergraduate engineering education. International Journal of Engineering Education, 23(2), 218-230. http://dx.doi.org/0949-149X/91.

Jesiek, B. K., Borrego, M., Beddoes, K., Hurtado, M., Rajendran, P., \& Sangam, D. (2011). Mapping global trends in engineering education research, 2005-2008. International Journal of Engineering Education, 27(1), 77-90.

Jollands, M., Jolly, L., \& Molyneaux, T. (2012). Project-based learning as a contributing factor to graduates' work readiness. European Journal of Engineering Education, 372), 143-154. http://dx.doi.org/10.1080/03043797.2012.665848.

Kumar, S., \& Hsiao, J. K. (2007). Engineers learn "soft skills the hard way": planting a seed of leadership in engineering classes. Leadership and Management in Engineering, 71), 18-23. http://dx.doi.org/10.1061/(ASCE)1532-6748(2007)7:1(18).

Lehmann, M., Christensen, P., Du, X., \& Thrane, M. (2008). Problem-oriented and project-based learning (POPBL) as an innovative learning strategy for sustainable development in engineering education. European Journal of Engineering Education, 33(3), 283295. http://dx.doi.org/10.1080/03043790802088566.

Macías, J. A. (2012). Enhancing project-based learning in software engineering lab teaching trough an e-portfolio approach. $l E E E$ Transactions on Education, 55(4), 502-507. http://dx.doi.org/10.1109/TE.2012.2191787.

Macías-Guarasa, J., Montero, J. M., San-Segundo, R., Araujo, A., \& Nieto-Taladriz, 0. (2006). A project-based learning approach to design Electronic Systems Curricula. IEEE Transactions on Education, 49(3), 389-397. http://dx.doi.org/10.1109/TE.2006.879784.

Mantri, A., Dutt, S., Gupta, J. P., \& Chitkara, M. (2008). Design and evaluation of a PBL-based course in analog electronics. IEEE Transactions on Education, 51(4), 432-438. http://dx.doi.org/10.1109/TE.2007.912525.

Martinez-Mones, A., Gomez-Sanchez, E., Dimitriadis, Y. A., Jorrin-Abellan, I. M., Rubia-Avi, B., \& Vega-Gorgojo, G. (2005). Multiple case studies to enhance project-based learning in a computer architecture course. IEEE Transactions on Engineering Education, 48(3), 482-489. http://dx.doi.org/10.1109/TE.2005.849754.

McLurkin, J., Rykowski, J., John, M., Kaseman, Q., \& Lynch, A. J. (2013). Using multi-robot systems for engineering education: Teaching and outreach with large numbers of an advanced, low-cost robot. IEEE Transactions on Education, 56(1), 24-33. http://dx.doi. org/10.1109/TE.2012.2222646.

Meho, L. 1. (2007). The rise and rise of citation analysis. Physics World, 20(1), 32-36. http://dx.doi.org/10.1088/2058-7058/20/1/33.

Mitchell, J. E., Canavan, B., \& Smith, J. (2010). Problem-based learning in communication systems: student perceptions and achievement. IEEE Transactions on Education, 53(4), 587-594. http://dx.doi.org/10.1109/TE.2009.2036158.

Montero, E., \& González, M. J. (2009). Student engagement in a structured problem-based approach to learning: a first-year electronic engineering study module on heat transfer. IEEE Transactions on Education, 52(2), 214-221. http://dx.doi.org/10.1109/TE.2008.924219.

Palmer, S., \& Hall, W. (2011). An evaluation of a project-based learning initiative in engineering education. European Journal of Engineering Education, 36(4), 357-365. http://dx.doi.org/10.1080/03043797.2011.593095.

Pandy, M. G., Petrosino, A. J., Austin, B. A., \& Barr, R. E. (2004). Assessing adaptive expertise in undergraduate biomechanics. Journal of Engineering Education, 93(3), 211-222. http://dx.doi.org/10.1002/j.2168-9830.2004.tb00808.x.

Prince, M. J., \& Felder, R. M. (2006). Inductive teaching and learning methods: definitions, comparisons, and research base. Journal of Engineering Education, 95(2), 123-138. http://dx.doi.org/10.1002/j.2168-9830.2006.tb00884.x.

Ragusa, G., \& Lee, C. T. (2012). The impact of focused degree projects in chemical engineering education on students' research performance, retention, and efficacy. Education for Chemical Engineers, 7(3), 69-77. http://dx.doi.org/10.1016/j.ece.2012.03.001.

Ríos, 1., Cazorla, A., Díaz-Puente, J. M., \& Yagüe, J. L. (2010). Project-based learning in engineering higher education: two decades of teaching competences in real environments. Procedia: Social and Behavioral Sciences, 2(2), 1368-1378. http://dx.doi.org/10.1016/j. sbspro.2010.03.202.

Rodríguez, J., Laverón-Simavilla, A., del Cura, J. M., Ezquerro, J. M., Lapuerta, V., \& Cordero-Gracia, M. (2015). Project Based Learning experiences in the space engineering education at Technical University of Madrid. Advances in Space Research, 56(7), 1319-1330. http://dx.doi.org/10.1016/j.asr.2015.07.003.

Salton, G., \& McGill, M. J. (1983). Introduction to modern information retrieval. New York: Mc-Graw Hill.

Sancho, P., Fuentes-Fernandez, R., Gomez-Martin, P. P., \& Fernandez-Manjon, B. (2009). Applying multiplayer role-based learning in engineering education: three case studies to analyze the impact on students' performance. International Journal of Engineering Education, 25(4), 665-679. Retrieved in 2 March 2017, from http://www.e-ucm.es/drafts/e-UCM_draft_136.pdf

Santos-Martin, D., Alonso-Martinez, J., Carrasco, E., \& Arnaltes, S. (2012). Problem-based learning in wind energy using virtual and real setups. IEEE Transactions on Education, 55(1), 126-134. http://dx.doi.org/10.1109/TE.2011.2151195.

Smith, K. A., Sheppard, S. D., Johnson, D. W., \& Johnson, R. T. (2005). Pedagogies of engagement: classroom-based practices. Journal of Engineering Education, 94(1), 1-15. http://dx.doi.org/10.1002/j.2168-9830.2005.tb00831.x.

Soares, F., Leão, C. P., Carvalho, V., Vasconcelos, R. M., \& Costa, S. (2014). Automation and control remote laboratory: a pedagogical tool. International Journal of Electrical Engineering Education, 51(1), 54-67. http://dx.doi.org/10.7227/1JEEE.51.1.5.

Soares, F. 0., Sepúlveda, M. J., Monteiro, S., Lima, R. M., \& Dinis-Carvalho, J. (2013). An integrated project of entrepreneurship and innovation in engineering Education. Mechatronics, 23(8), 987-996. http://dx.doi.org/10.1016/j.mechatronics.2012.08.005. 
Somerville, M., Anderson, D., Berbeco, H., Bourne, J. R., Crisman, J., Dabby, D., Donis-Keller, H., Holt, S. S., Kerns, S., Kerns, D. V., Martello, R., Miller, R. K., Moody, M., Pratt, G., Pratt, J. C., Shea, C., Schiffman, S., Spence, S., Stein, L. A., Stolk, J. D., Storey, B. D., Tilley, B., Vandiver, B., \& Zastavker, Y. (2005). The Olin curriculum: thinking toward the future. IEEE Transactions on Education, 48(1), 198-205. http://dx.doi.org/10.1109/TE.2004.842905.

Song, J. W., \& Chung, K. C. (2010). Observational studies: cohort and case control studies. Plastic and Reconstructive Surgery, 126(6), 2234-2242. PMid:20697313. http://dx.doi.org/10.1097/PRS.0b013e3181f44abc.

Steinemann, A. (2003). Implementing sustainable development through problem-based learning: pedagogy and practice. Journal of Professional lssues in Engineering Education and Practice, 129(4), 216-224. http://dx.doi.org/10.1061/(ASCE) 1052-3928(2003) 129:4(216).

Taajamaa, V., Kirjavainen, S., Repokari, L., Sjöman, H., Utriainen, T., \& Salakoski, T. (2013). Dancing with Ambiguity Design thinking in interdisciplinary engineering education. In Proceedings of the 2013 IEEE Tsinghua International Design Management Symposium (TIDMS), Shenzhen, China. http://dx.doi.org/10.1109/TIDMS.2013.6981258.

The Institute for Scientific Information. (1994). The Thomson Reuters impact factor. Retrieved in 24 August 2017, from http://wokinfo. com/essays/impact-factor/?utm_source=false\&utm_medium=false\&utm_campaign=false

Tseng, K., Chang, C., Lou, S., \& Chen, W. (2013). Attitudes towards science, technology, engineering and mathematics (STEM) in a project-based learning (PjBL) environment. International Journal of Technology and Design Education, 23(1), 87-102. http://dx.doi. org/10.1007/s10798-011-9160-x.

United Nations Educational, Scientific and Cultural Organization - UNESCO. (2010). Engineering: issues, challenges and opportunities for development. United Nations educational, scientific and cultural organization. Paris: UNESCO Publishing.

Vallim, M. B. R., Farines, J. M., \& Cury, J. E. R. (2006). Practicing engineering in a freshman introductory course. IEE Transactions on Engineering, 49(1), 74-79. http://dx.doi.org/10.1109/TE.2005.856157.

Vieira, E. S., \& Gomes, J. A. N. F. (2009). A comparison of Scopus and Web of Science for a typical university. Scientometrics, 81(587), 587-600. http://dx.doi.org/10.1007/s11192-009-2178-0.

Wang, Y., Yu, Y., Wiedmann, H., Xie, N., Xie, C., Jiang, W., \& Feng, X. (2012). Project based learning in mechatronics education in close collaboration with industrial: methodologies, examples and experiences. Mechatronics, 22(6), 862-869. http://dx.doi.org/10.1016/j. mechatronics.2012.05.005.

Wankat, P. C. (2004). Analysis of the first ten years of the Journal of Engineering Education. Journal of Engineering Education, 93(1), 13-21. http://dx.doi.org/10.1002/j.2168-9830.2004.tb00784.x.

Wankat, P. C., Williams, B., \& Neto, P. (2014). Enginereing education research in European Journal of Engineering Education and Journal of Engineering Education: citation and reference discipline analysis. European Journal of Engineering Education, 39(1), 7-17. http://dx.doi.org/10.1080/03043797.2013.867316.

Warren, S. J., Dondlinger, M. J., Mcleod, J., \& Bigenho, C. (2012). Opening the door: an evaluation of the efficacy of a problem-based learning game. Computers \& Education, 58(1), 347-412. http://dx.doi.org/10.1016/j.compedu.2011.08.012.

Weitzel, S. R. (2006). Fluxo da informação científica. In D. A. Plobacion (Ed.), Comunicação e produção científica: contexto, indicadores, avaliação (pp. 83-114). São Paulo: Angellara.

Xian, H., \& Madhavan, K. (2014). Anatomy of the scholarly collaboration in engineering education: a big-data bibliometric analysis. Journal of Engineering Education, 103(3), 486-514. http://dx.doi.org/10.1002/jee.20052.

Yadav, A., Subedi, D., Lundeberg, M. A., \& Bunting, C. F. (2011). Problem-based learning: Influence on students' learning in an electrical engineering course. Journal of Engineering Education, 100(2), 253-280. http://dx.doi.org/10.1002/j.2168-9830.2011.tb00013.x.

Zhao, D., \& Logan, E. (2002). Citation analysis using scientific citations on the Web as a data source: a case study in the XML research area. Scientometrics, 54(3), 449-472. http://dx.doi.org/10.1023/A:1016090601710.

Zou, C., Kolmos, A., \& Nielsen, J. F. D. (2012). A problem and Project-Based Learning (PBL) approach to motivate group creativity in engineering education. International Journal of Engineering Education, 28(1), 3-16. Retrieved in 2 March 2017, from http://www. ijee.ie/contents/c280112.html

Received: Oct. 14, 2016

Accepted: June 19, 2017 
Appendix A. List of reviewed papers.

Authors/Year

Behrens et al. (2010)

Bellmunt et al. (2006)

Bielefeldt et al. (2010)

Chandrasekaran et al. (2013)

Chau (2007)

Chinowsky et al. (2006)

Costa et al. (2007)

Crosthwaite et al. (2006)

De Graaff \& Kolmos (2003)

De los Ríos-Carmenado et al. (2015)

Ditcher (2001)

Doppelt (2009)

Fernandes et al. (2012)

Frank et al. (2003)

Garcia \& Pacheco (2014)

Gomes et al. (2006)

Gomez-de-Gabriel et al. (2011)

Hersam et al. (2004)

Hosseinzadeh \& Hesamzadeh (2012)

Huntzinger et al. (2007)

Jollands et al. (2012)

Kumar \& Hsiao (2007)

Macías (2012)

Macías-Guarasa et al. (2006)

Mantri et al. (2008)

Martinez-Mones et al. (2005)

Mclurkin et al. (2013)

Mitchell et al. (2010)

Montero \& González (2009)

Palmer \& Hall (2011)

Pandy et al. (2004)

Prince \& Felder (2006)

Ragusa \& Lee (2012)

Rodríguez et al. (2015)

Sancho et al. (2009)

Santos-Martin et al. (2012)

Soares et al. (2014)

Soares et al. (2013)

Somerville et al. (2005)

Steinemann (2003)

Tseng et al. (2013)

Vallim et al. (2006)

Wang et al. (2012)

Warren et al. (2012)

Yadav et al. (2011)
Title

MATLAB meets LEGO Mindstorms: a freshman introduction course into practical engineering

A distance PLC programming course employing a remote laboratory based on a flexible manufacturing cell Measuring the Value Added from Service Learning in Project-Based Engineering Education

Project-oriented design-based learning: aligning students' views with industry needs Incorporation of sustainability concepts into a civil engineering curriculum

Developing knowledge landscapes through project-based learning

Applying the problem-based learning approach to teach elementary circuit analysis

Balancing Curriculum Processes and Content in a Project Centred Curriculum: In Pursuit of Graduate Attributes

Characteristics of problem-based learning

Promoting professional project management skills in engineering higher education: project-based learning (PBL) strategy

Effective Teaching and Learning in Higher Education, with Particular Reference to the Undergraduate Education of Professional Engineers

Assessing creative thinking in design-based learning

Students' views of assessment in project-led engineering education: findings from a case study in Portugal Implementing the project-based learning approach in an academic engineering course

Using TSPi and PBL to Support Software Engineering Education in an Upper-Level Undergraduate Course Chemical Engineering Curriculum Renewal

Using LEGO NXT Mobile Robots With LabVIEW for Undergraduate Courses on Mechatronics

Implementation of interdisciplinary group learning and peer assessment in a nanotechnology engineering course

Application of project-based learning (PBL) to the teaching of electrical power systems engineering

Enabling sustainable thinking in undergraduate engineering education

Project-based learning as a contributing factor to graduates' work readiness

Engineers learn "soft skills the hard way": Planting a seed of leadership in engineering classes

Enhancing Project-Based learning in Software Engineering Lab Teaching Through an E-Portfolio Approach

A project-based learning approach to design Electronic Systems Curricula

Design and evaluation of a PBL-based course in analog electronics

Multiple case studies to enhance project-based learning in a computer architecture course

Using multi-robot systems for engineering education: Teaching and outreach with large numbers of an advanced, low-cost robot

Problem-based learning in communication systems: Student perceptions and achievement

Student engagement in a structured problem-based approach to learning: A first-year electronic engineering study module on heat transfer

An evaluation of a project-based learning initiative in engineering education

Assessing adaptive expertise in undergraduate biomechanics

Inductive teaching and learning methods: Definitions, comparisons, and research bases

The impact of focused degree projects in chemical engineering education on students' research performance, retention, and efficacy

Project Based Learning experiences in the space engineering education at Technical University of Madric Applying Multiplayer Role-Based Learning in Engineering Education: Three Case Studies to Analyze the Impact on Students' Performance

Problem-based learning in wind energy using virtual and real setups

Automation and control remote laboratory: a pedagogical tool

An integrated project of entrepreneurship and innovation in engineering education

The Olin curriculum: Thinking toward the future

Implementing sustainable development through problem-based learning: Pedagogy and practice

Attitudes towards science, technology, engineering and mathematics (STEM) in a project-based learning (PjBL) environment

Practicing engineering in a freshman introductory course

Project based learning in mechatronics education in close collaboration with industrial: Methodologies, examples and experiences

Opening the Door: An evaluation of the efficacy of a problem-based learning game

Problem-based learning: Influence on students' learning in an electrical engineering course 